\title{
Corrigendum
}

\section{Bcl-xL controls a switch between cell death modes during mitotic arrest}

\author{
N Bah, L Maillet, J Ryan, S Dubreil, F Gautier, A Letai, P Juin and S Barillé-Nion
}

Cell Death and Disease (2014) 5, e1429; doi:10.1038/cddis.2014.436; published online 2 October 2014

Correction to: Cell Death and Disease (2014) 5, e1291; doi:10.1038/cddis.2014.251; published online 12 June 2014

Since the publication of this article the authors have noticed an error in Figure 7c. pS62DBcl-xL and pS62ABcl-xL are in the wrong order. The corrected figure is shown here.

The corrected article appears online together with this corrigendum. The authors would like to apologize for any inconvenience caused. a

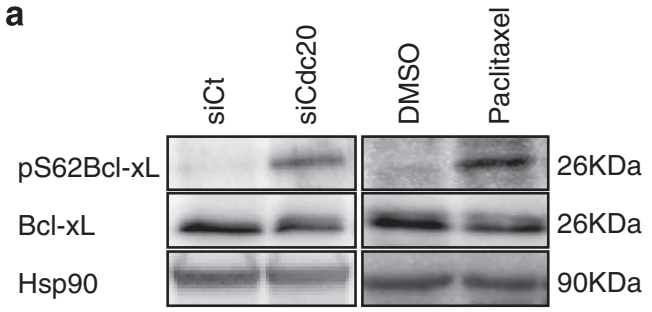

b

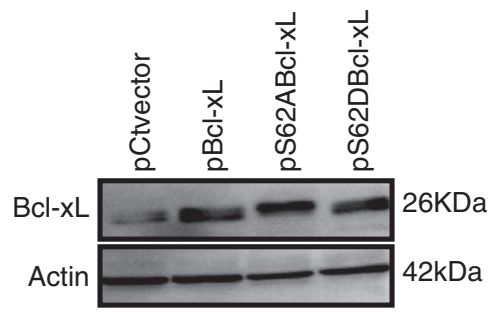

C

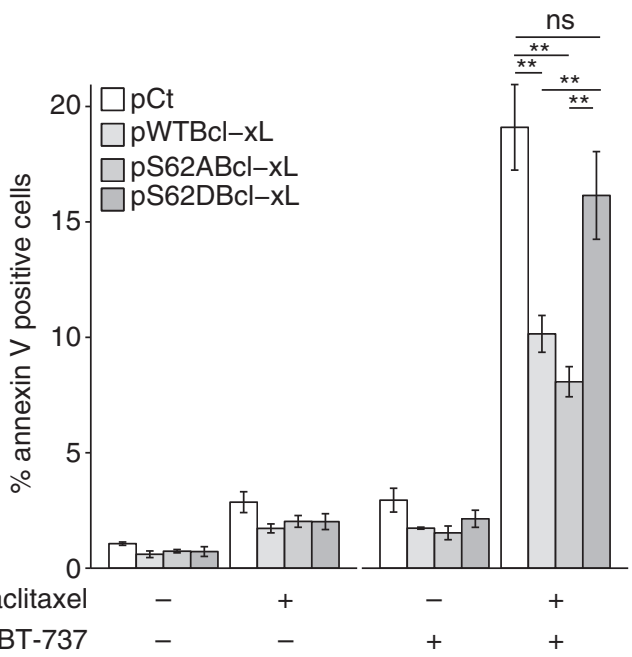

Figure 7 Serine 62 phosphorylation of $\mathrm{BCl}-\mathrm{xL}$ occurring during prolonged mitotic arrest, promoted mitotic cell apoptosis. (a) Immunoblot analysis of $S 62$ phosphorylation of $\mathrm{Bcl}-\mathrm{xL}$ ( $\mathrm{pS62Bcl-xL)}$ expression levels after Cdc20 depletion or paclitaxel treatment. MDAMB-231 cells were transfected with either control or Cdc20 siRNA for $48 \mathrm{~h}$ or treated with paclitaxel for $12 \mathrm{~h}$, harvested and the expression level of pS62Bcl-xL were finally evaluated by immunoblot analysis with S62-phospho-specific or total Bcl-xL antibodies. (b) Immunoblot analysis of Bcl-xL mutants. MDA-MB-231 cells were transfected with plasmids coding for wt $\mathrm{Bcl}-\mathrm{xL}$ or S62(A or $\mathrm{D}) \mathrm{Bcl}-\mathrm{xL}$ mutants and analysed by immunoblotting $48 \mathrm{~h}$ later. (c) Apoptosis analysis of MDA-MB-231 cells after Bcl-xL or its S62 mutants (S62A- or S62D-Bcl-xL) overexpression, and treatment or not with paclitaxel and ABT-737, compared with control cells. MDA-MB-231 cells were transfected, respectively, with control plasmid $(\mathrm{pCt})$, plasmids coding for $\mathrm{Bcl}-\mathrm{xL}(\mathrm{pBCl}-\mathrm{xL})$ or its $\mathrm{S} 62(\mathrm{~A}$ or D) mutants (pS62(A or D)Bcl-xL). Cells were then treated with either DMSO or paclitaxel $(70 \mathrm{nM})$, and finally stained with Annexin-V, and analysed by flow cytometry 